\title{
SLOW FOOD HAREKETİNE UYGUN BİR İÇECEK: TÜRK KAHVESI
}

\author{
A DRINK BEFITTING THE SLOW FOOD MOVEMENT: TURKISH COFFEE
}

\section{Leyla ÖZGEN* - Pervin ERGUN** Elif KAYMAZ ${ }^{* * *}$}

\begin{abstract}
ÖZ: Başlangıçta Araplar tarafından sadece kaynatılarak içilen kahve, Türk damak tadı gereği kavrularak, ögütülerek, "ağır ateşte yavaş" pişirilmesiyle dünyada da bugünkü anlamda "Slow Food"un ilk kahve pişirme tekniği olduğu söylenebilir. Kahve, dünyaya Türkler üzerinden yayılmıș ve o kadar Türklükle özdeşleşmiştir ki Türk kültürünün yaygınlaşmasının önüne geçmek için pek çok ülkede, özellikle dini ve ulusal kimlik kodları üzerinden önlemler alınmaya çalışılmıştır. Geçen zaman içinde dünyada kahve geleneğinde değişmeler görülmüştür. Bu kültürel değiş̧imlerden Türk kahvesi de nasibini almış; özellikle "ele alınıp götürülebilen (take away) kahve" formatının eklenmesi söz konusu olmuștur. Bu durum Türk kahvesinin hem hazır kahveye (instant) dönüşmesinin hem de melezleşmeye başlamasının göstergesi olarak kabul edilebilir. Türk kahvesi bu şekilde bir taraftan melezleşme eğilimi gösterirken diğer taraftan karakteristik standartlarını belirleme ve koruma çalıșmalarına konu olmuştur. Özellikle İtalya'da Fast Food'a tepki olarak ortaya çıkan Slow Food Hareketinin, ülkelere, yörelere özgü yemekleri korumak ve tarım alanlarındaki biyolojik çeşitliliğe sahip çıkma akımı açısından Türk kahvesi oldukça karakteristik özellikler taşımaktadır. Osmanlı Saray mutfağının beş yüz yıllık tarihi kahve serüveninden bugüne aktarılan bir içecek olması, kısık ateşte yavaş pişirme metodunun uygulanması ve sohbet aracı olması bu özelliklerinden birkaçıdır. Türk kahvesi, Slow Food hareketinin "iyi, temiz ve adil" felsefesine uygun bir içecek olarak tanımlanabilir. Bu bağlamda Eko Gastronomi turizmi aracılığılla sempozyumların, kongrelerin, workshopların düzenlenmesi, kahvenin hazırlanma, pişirilme ve ikram şekillerinin görsel olarak yapılması sağlanmalıdır. Ayrıca bu esnada Türk kahvesiyle ilgili somut olmayan kültürel miras kapsamına giren bütün ritüeller oluşturulmalıdır.
\end{abstract}

Anahtar Kelimeler: Slow food içeceği, melezleșme, Türk kahvesi, kültür.

ABSTRACT: Originally just boiled before consumption by Arabic people, Turkish coffee - roasted, ground and brewed slowly on low heat - can be considered the first slow coffee in the contemporary sense. Coffee spread to the world via the Turks and it is so thoroughly identified with Turkishness that many nations tried to implement measures, especially through religious and national identity codes, to prevent the dissemination of Turkish culture. In time, Turkish coffee was gradually influenced by the growing coffee culture across the globe, particularly with the emergence of take away coffee, which can be regarded as an indication of both the transformation of

\footnotetext{
${ }^{*}$ Doç. Dr. - Gazi Üniversitesi Sağlık Bilimleri Fakültesi Sosyal Hizmet Bölümü/Ankara lozgen@gazi.edu.tr

** Doç. Dr. - Ankara Hacı Bayram Veli Üniversitesi Edebiyat Fakültesi Türk Halk Bilimi Bölümü/Ankara - pervinergun@gmail.com

*** Arș. Gör. - Sakarya Uygulamalı Bilimler Üniversitesi Turizm Fakültesi Gastronomi ve Mutfak Sanatları Bölümü/Sakarya - elif.kaymaz.az@gmail.com
} 
Turkish coffee into instant coffee and the incipience of its hybridization. Alongside this hybridization tendency, Turkish coffee has also been the subject of efforts to designate and preserve its characteristic standards. Turkish coffee characteristics are very suitable for the Slow Food Movement, which was founded in Italy as a reaction to fast food, particularly with regard to preserving regional and national cuisines and protecting agricultural biodiversity. Both the method of slow brewing on low heat and the tradition of slow drinking - due to its hotness and function as an instrument of conversation - of Turkish coffee must be observed and sustained as a 500-year historical heritage as a part of the Ottoman palace cuisine. Turkish coffee can be characterized as a beverage that befits the philosophy of "good, clean and fair food" of the Slow Food Movement. Concordantly, symposiums, conferences and workshops must be organized in the scope of eco-gastronomic tourism to provide visual presentation of Turkish coffee preparation, brewing and service, meanwhile performing each ritual as part of the intangible cultural heritage of Turkish coffee.

Keywords: Slow food beverage, hybridization, Turkish coffee, culture.

\section{Giriş}

Etiyopya'nın Kaffa bölgesinden 14. yy'da Yemen'e geldiği düşünülen, 16. yy'dan itibaren de Türkler tarafından keşfedilen kahve, sonraki beş yüz yıllık süreçte dünya mutfaklarında yerini almıștır (Bulduk ve Süren, 2007: 301; Akşit Așık, 2017: 311). Başlangıçta Araplar tarafından sadece kaynatılarak içilen kahve, Türk damak tadı gereği kavrularak, öğütülerek, "ağır atește yavaş" pişirilmesiyle dünyada da bugünkü anlamda "Slow Food"a uygun pişirme tekniği olarak söylenebilir. Kahve dünyaya Türkler üzerinden yayılmış ve o kadar Türklükle özdeşleşmiştir ki Türk kültürünün ve ekonomik değerinin yaygınlaşmasının önüne geçmek için pek çok ülkede, özellikle dini ve ulusal kimlik kodları üzerinden önlemler alınmaya çalışılmıştır. Örneğin Almanya'da politik sebeplerle yasaklanmış; Papa tarafından da Müslüman-Türk içkisi olarak nitelendirilerek yasaklanmıştır (Toros, 1998: 30, 71). Hatta kahve içenlerin Türkleşeceği, Müslümanlaşacağı belirtilmiştir (Sheridan, 2004: 25). Başlangıçta özellikle tarikatlarda yaygınlaşan ve olağanüstü özellikler atfedilen kahve, Osmanlı padişahları tarafından da çeşitli zamanlarda yasaklanmıştır. Bütün bu yasaklamalara rağmen gerek Osmanlı coğrafyasında gerekse Osmanlı etkisi üzerinden tüm dünyada hızla yaygınlaşmıştır. Bu sürecin bir sonucu olarak Osmanlılar 17. yy'ın başlarından itibaren kahvenin Venedik, Marsilya, Paris, Londra ve diğer Avrupa şehirlerinde tanınmasına neden olmuştur (Kuzucu ve Koz, 2015: 101,102). Türk kahvesinin Türk kültüründeki kullanım yaygınlığını, 19 yy'da Edmondo: "Kahve artık her yerde, Galata ve Serasker kulelerinin tepesinde, bütün vapurlarda, mezarlıklarda, berber dükkânlarında, hamamlarda, çarşılarda içilmektedir. İstanbul'un neresinde olursanız olun, dönüp dolaşıp aranmanıza gerek olmaksızın, 'Kahveci!' diye bağırmanız yeterlidir, üç dakika sonra önünüzde bol köpüklü ve bol telveli dumanı tüten bir fincan kahve hazırdır" şeklinde ifade etmiştir (Kuzucu ve Koz, 2015: 138). Giddens de kahvenin sadece bir içecek olmadığını, gündelik toplumsal etkinliklerin simgesel bir değeri oldu- 
ğunu; birinin bir fincan kahve içmesinin kişisel bir tören ama bunu başkalarıyla birlikte yapmasının toplumsal bir tören olduğunu belirtmiștir (2004: 39).

Kahveyle ilgili zengin birikim nedeniyle "Türk kahvesi kültürü ve geleneği", 2013 yllında UNESCO tarafından "İnsanlığın Somut Olmayan Kültürel Mirası Temsili Listesi”nde Türklüğe ait bir sembol kabul edilerek tescillenmiștir (URL-1). Türkler tarımsal anlamda kahve üreticisi olmamakla birlikte kahveyi "işleme (kavurma, soğutma, öğütme, saklama), pişirme, sunma aşamalarında bakır, demir, gümüss, oya, dantel, her tür kumaş işçiliği, porselen, ahşap oymacılığı, şekercilik, lokumculuk" gibi pek çok zanaat sektörünü geliştirmiştir. Ayrıca edebiyattan sinemaya, kahvehane kültüründen halıcılığa ve falcılığa kadar kapsama alanını genişletmiştir (Gürsoy Naskali, 2011). Herhalde Türkiye'de gerek amatör gerek profesyonel anlamda en fazla koleksiyon, kahve kültürü ve geleneği üzerine bulunmaktadır. Türk kültüründe kahveye bu şekilde çeşitli roller atfedilmesi ve geleneğin dünyaya özgün şekliyle taşınması başlangıçta yurt dışında da bazı zanaatlarla ilgili koleksiyonları etkilemiştir. Bunlar içinde özellikle Türk kahvesi fincanı üretimi ve pazarlaması önemli bir sektör oluşturmuştur.

Türk kahvesiyle ilgili önemli bir husus falcllıktır. Gerek sözlü gerekse sanal bellekte bütün canlılığıyla büyümeye devam eden kahve falı kültürü, bu işle uğraşan kişilerin ve internet sitelerinin sayısını hızla artırmaktadır. Bunların sadece sayısı artmakla kalmamakta, falcılar ve fal siteleri gerek bireysel uygulamalarda gerekse toplum hayatının çeșitli katmanlarında günlük hayatın bir parçası haline gelmektedirler. Bütün bu özellikleriyle Türk kahvesi, kendine has kültürü ve geleneği ile dünya kahve kültürü içinde özgün bir sembol olarak listeye alınmayı hak etmiş görünmektedir (URL-1).

Türk kahvesinin, Somut Olmayan Kültürel Miras listesine eklenmesi, bu içeceğin melezlik özelliği taşımaya başlamasının göstergesi olarak da algılanmıştır. Toplumları belirleyen kültürlerde ikili karşıtlıkların zorunlu görüldügü merkez-çevre, kendi-öteki gibi ötekileştirici ifadeler, daha etkin bir şekilde yer edinmeye başlamıştır. Farklı kültürlerin yorumlanmasında melezliğin üzerinde durulmasının sebebi birbirinden farklı olan iki kültürün bir araya gelme alanının bizim/sizin ilişkisi dışında yorumlanmasıdır (Demirkol, 2013: 26). Melezlik, dünyanın farklı ülkelerinde, farklı bölgelerinde bulunan bireylerin kültürlerinin birbirleri ile sentezlenmesidir (Küçük ve Kahyaoğlu, 2013: 10). Hannerz de "melez (creole) ve yaratma (create) arasındaki benzerlikler rastlantısal değildir. (...) Melezleşme biraz kaybetmeyi ama biraz da kazanmayı içerebilir" ifadesi ile melezliğin özelliklerini biraz daha anlaşılır hale getirmiştir (1998: 161, 163). Bireylerin içinde yaşadıkları toplumun standartları, yaşama biçimlerinin ve yeme içme kültürünün şekillenmesinde önemli rol oynamaktadır. Kültürel değişimler bu bağlamda Türk kahvesini de etkileyerek özellikle "ele alınıp götürülebilen (take away) kahve" formatının eklenmesine neden olmuştur. Bu durum Türk kahvesinin hem hazır 
kahveye (instant) dönüşmesinin hem de melezleşmeye başlamasının göstergesi olarak kabul edilebilir (Akarçay, 2012: 195; Akşit Aşılk, 2017: 311, 312).

Türk kahvesi, bu şekilde bir taraftan melezleşme eğilimi gösterirken diğer taraftan karakteristik standartlarını belirleme ve koruma çalıșmalarına konu olmaktadır. Örneğin 24 Mayıs 2017'de Kültür ve Turizm Bakanlığı himayesinde Türk Kahvesi Kültürü ve Geleneği Derneği'nin öncülüğünde Mutfak Sanatları Enstitüsü'nde gerçekleștirilen çalıştayda, ithalattan kavurmaya, dövmekten pişirmeye ve sunuma kadar her aşamanın bir standarda bağlanması için pek çok alandan uzmanın görüş ve önerileri alınmıştır. Katılımcısı olduğumuz çalıştaydan çıkan genel sonuç, Türk kahvesinin geleneksel özelliklerinin korunarak bir standardının olușturulması temeline dayandırılmıştır (URL-2). Bu bağlamda Türk kahvesi, özellikle İtalya'da Fast Food'a tepki olarak ortaya çıkan Slow Food Hareketinin, ülkelere, yörelere özgü yemekleri korumak ve tarım alanındaki biyolojik çeşitliliğe sahip çıkma akımı açısından oldukça karakteristik özellikler taşımaktadır (Güven, 2011: 114, 115). İtalya'da başlayan bu hareket, 1986 yllında Mc Donald's açıldığında yapılan protesto ile ortaya çıkmıştır (Güven, 2011: 114, 115).

Slow Food hareketi, İtalya'da başlamakla birlikte Türkiye ve diğer bazı ülkelerde yaygınlaşmaya başlamıştır. Türkiye'de bu harekete en uygun içeceklerden biri Türk kahvesidir. Türk kahvesi, hem gastronomi turizmi içinde Slow Food hareketine uygun bir içecek olması hem de farklı iki kültürün yorumlanması açısından oldukça önemlidir. Osmanlı Saray mutfağının beş yüz yıllık kahve serüveni içinden bugüne aktarılan bu içecek, hem kısık ateşte yavaş pişirme metodunun sürdürülmesi hem de sıcak içilmesi ve sohbet aracı olması nedeniyle önemlidir.

Gastronomi turizminde son yıllarda artan bir öneme sahip olan Slow Food hareketinde, yerel yiyecek ve içecekler, "iyi, temiz ve adil" felsefesine uygunluk açısından değerlendirilmektedir. Bu çalışmada "Türk kahvesi" söz konusu hususlar açısından doküman analizi yöntemiyle incelenmiştir. 16. yy. Osmanlı'sından bugüne kahve, geleneksel olarak cezve içinde pişirilmiştir. Fakat günümüzde filtre kahve tekniğinin yaygınlaşması (Kuzucu ve Koz, 2015: 313) ve Türk kahvesinin de hızlı teknolojiden etkilenerek granül (instant) hale dönüştürülmesi sonucu melezleşmesi ile son yıllarda geleneksel özelliğini kaybetme eğilimi göstermiştir. Bu çalışmada, Türk kahvesinin Slow Food içeceği olarak belirlenmesi amaçlanmış ve "Türk kahvesi Slow Food içeceği olarak iyi midir"; "Türk kahvesi Slow Food içeceği olarak temiz midir"; "Türk kahvesi Slow Food içeceği olarak adil midir" sorularına cevap aranmıştır.

\section{Yöntem}

Bu çalışmada betimsel tarama modeli kullanılmıştır. Nitel çalışma türü olarak Gömülü (Örtük) teori kullanılmıștır. Gömülü teorideki veriler geniş çeşitlilikteki doküman materyallerden, sürekli karşılaştırma metodundan meydana geldiği şeklinde tanımlanmıștır (Merriam, 2015). 


\section{Verilerin Toplanması}

Araştırmada veriler, doküman incelemesi yoluyla toplanmıştır. Doküman incelemesi, araştırılacak konular hakkında bilgi içeren yazılı materyallerin analizini kapsayan mevcut kayıt ya da belgelerin, veri kaynağı olarak sistemli incelenmesidir. Başarılı bir doküman incelemesinin temel şartı, konuya ilişkin belgelerin bulunması, incelenmesi ve belli durum ya da görüşleri ortaya çıkartacak bir senteze varılabilmesi için gerekli düzenlemelerin yapılabilmesidir (Yıldırım ve Şimşek, 2006: 146; Karasar, 2007: 140). Doküman incelemesinde makalelerin ve kitapların değerlendirilmesi sürecinde aşağıdaki adımlar sırası ile gerçekleştirilmiştir:

1. Türk Kahvesi'nin Slow Food hareketine uygun bir içecek olduğuna ilişkin yapılan makalelere ulaşılmış;

2. Araştırmacılar tarafından önceden belirlenen temalara ilişkin değerlendirmeler yapılmış;

3. Doküman incelemesi ile elde edilen araştırma verileri yorumlanmıştir.

\section{Verilerin Analizi}

Verilerin analizi aşamasında içerik analizi tekniği ile araștırmalar karşılaştırmalı olarak çözümlenmeye çalışılmıştır. İçerik analizi türlerinden doküman analizi tekniği kullanılarak kavram hakkında derinlemesine inceleme yapılmaya çalıșılmıştır. Doküman analizi araştırmanın hedeflerine yönelik verilere ulaşmada dokümanların incelenmesi ile gerçekleşmektedir (Çepni, 2010). Bu çalışmada da, geleneksel kültürde yaşadığı şekliyle Türk kahvesinin Slow Food hareketinin "iyi, temiz ve adil" felsefesine uygunluğu doküman analizi ile incelenmiștir.

\section{Bulgular ve Tartışma}

Slow Food hareketine uygun bir içecek olup olmadığı Türk kahvesinin doküman analiziyle incelenmesi sonucunda şu bulgular elde edilmiştir:

\section{“İyi” Kavramı Açısından Türk Kahvesi}

Çakır vd., Slow Food hareketine göre bir gıdanın ve içeceğin "iyi" olarak nitelendirilebilmesi için "yerel bir kültürün parçası olması, kendine özgü pişirme yönteminin, araç-gereçlerinin, ikram edilme usulünün olması" gerektiğini belirtmiştir (2015: 63). Işıkhan da çalışmasında, Slow Food ürünlerinin saklandığı, servis edildiği araç-gereçlerin "kendine özgü" olduğunu ifade etmiştir (2014: 412). Keskin ise "iyi" gıda kavramını Slow Food açısından incelediğinde, "ürünün tat, aroma ve görünüşünün kendine has olması, yapay olmaması" olarak nitelendirmiştir (2012: 88).

Slow Food hareketinin "iyi" kavramı açısından Türk kahvesinin duyusal analizi incelendiğinde kendine has tadının, kokusunun, renginin ve kıvamının olduğu; içerisinde binden fazla aroma maddesinin bulunduğu; bu 
aroma maddelerinin üç yüz ellisinin yeşil kahve çekirdeğinde, altı yüz ellisinin ise kavrulmuş ve pişirilmiş kahve çekirdeğinde olduğu belirlenmiștir. Kahve çekirdeklerinin kavrulması ile rengin koyulaştığı, aromanın arttığı, uçucu ve uçucu olmayan bileşenlerin ortaya çıktığı belirlenmiştir. Aynı zamanda kahvenin kavrulup pişirilmesinin tat ve aroma açısından önemli olduğu vurgulanmıştır (Özgür, 2012: 3; Ayseli, 2015: 2).

Slow Food hareketine göre Türk kahvesinin "iyi” olarak tanımlanabilmesi için iyi öğütülmesi ve nemli kalması gerektiği, öğütülmüş parçacıkların \%70 ila 75'inin ölçüsünün 75-125 mikron civarında olması gerektiği belirtilmiştir (Özgür, 2012: 1, 2).

Slow Food hareketine göre kahvenin "iyi" saklanabilmesi için Türk kahvesinin hemen öğütülüp pişirilmesi, öğütülen kahvenin hava, ışık ve nem almayan bir kutuya konulması gerekmektedir. Öğütülen kahvenin çok uzun süre saklanmaması en kısa süre içinde tüketilmesi kahvenin daha lezzetli olmasını sağlamaktadır (Özgür, 2012: 2).

Slow Food hareketine göre Türk kahvesinin "iyi" aroması için fındık, kakule, karanfil, mercanköşkü, sakız gibi geleneksel ve yaygın olarak tercih edilen aroma verici maddeler de katılabilmektedir. Bu noktada mühim olan hangi aromanın kullanıldığı ve bu aromaların özelliklerinin neler olduğunun belirtilmesidir (Özgür, 2012: 2).

Slow Food hareketine göre Türk kahvesinin "iyi" olarak nitelendirilmesi için köpük ve telve de önemli bir husus olarak kabul edilmektedir. Özgür tarafından belirtildiği üzere "köpügün esnek, küçük kabarcıklı, açık renk olması ve tüm yüzeyi kaplamasına gayret edilir. Fincanda $1 \mathrm{~cm}$ kalınlığında telve oluşması arzu edilir" şeklinde tarif edilmiştir (2012: 2). Saltan ve Kaya, diğer kahvelerden farklı olarak telvesi ile birlikte pişirildiği ve içildiği için Türk kahvesinde daha fazla kahve çekirdeği bulunduğunu, bu sayede kahve tadının daha çok alındığını belirtmiştir. Ayrıca, kahvenin üzerindeki köpügün kahvenin soğumasını ve kokusunu kaybetmesini geciktirdiğini ifade etmiştir (2018: 279, 289). Ulusoy çalışmasında, bireylerin büyük çoğunluğunun Türk kahvesini geleneksel damak tadına daha uygun bulduğunu, bol köpüklü ve güzel aroması nedeniyle diğer filtre kahvelere göre daha çok tercih ettiğini saptamıștır (2011: 9). Ayseli, Türk kahvesinin (Arabica) orta kavrulduğunda $\mathrm{pH}$ değerinin 4.85 iken çok kavrulduğunda 5.65 olduğunu belirtmiştir. Kavrulma ısısının artması ile birlikte içerisindeki organik asitlerin parçalanması sonucu pH değerinin yükseldiği ve asit miktarının azaldığı, kavurma işlemi ile de antioksidan etkisi bulunan bileşiklerin oluştuğunu ifade etmiştir. Bu nedenle, antioksidan açısından daha zengin olması sebebi ile Türk kahvesi tüketilirken az ve orta kavrulmuş kahve çekirdeklerinin kullanılması önerilmiştir (2015: 35, 38). Bu özellikler Türk kahvesinin Slow Food hareketinin hem duyusal tat açısından aromaya, kendine özgü pişirme tekniklerine ve servisine uyduğu hem de "iyi" kavramı ile örtüștüğü söylenebilir. 


\section{“Temiz” Kavramı Açısından Türk Kahvesi}

Çakır vd., Slow Food hareketini oluşturan "temiz" gıdayı, "doğaya, çevreye, insan sağlığına ve yeryüzündeki diğer canlıların sağlığına zarar vermeyecek şekilde gıdaların üretilmesi ve tüketilmesi gerektiği" şeklinde ifade etmişlerdir (2015: 64). Sanayileşme ile hızlanan bu tüketim anlayışı dünya kaynaklarının azalması ve üretimle oluşan atıkların artması şeklinde sonuçlanmaktadır (Karalar ve Kiraci, 2011: 63). Ortaya çıkan bu atıkların sebep olduğu çevre kirliliğini kontrol edebilmek amacıyla aktif karbonlar kullanılmaktadır. Türk kahvesinin de aktif karbon üretiminde kullanılabilirliği, çevreye yararlı bir ürün olduğunu göstermektedir (Hoştut vd., 2011: 3-4). Bir diğer araştırmada da Türk kahvesi telvesi ile atık sulardan ağır metallerin arındırılabildiği ifade edilmiștir (Akgün vd., 2013: 44).

Türk kahvesinin, Slow Food hareketinin "temiz" kavramı ile uygunluğunu gösteren ve çevreye katkı sağlayan bir diğer özelliği ise kahve telvesinde bulunan yağın ekstraksyon yöntemi ile ayrıştırılarak biyodizel üretiminde kullanılmasıdır. Biyodizel üretimi amacıyla Türk kahvesinin telvesinin ayrıștırıldığı araştırmada, petrolün doğaya verdiği zararı ve yağlı atıkların depolanması sorununu önlemesi sebebiyle biyodizelin çevre için önemi vurgulanmaktadır. Türk kahvesinin hem çok tüketilmesi ile daha fazla kahve atığının oluşması hem de içerdiği yağ oranı (\%10-15) biyodizel üretimi için uygun bir gida olduğunu göstermektedir. Bu sayede hem çevreye hem de ekonomiye katkı sağladığı ifade edilmiştir. Biyodizel üretiminin yanı sıra kahve telvesinden, bitki atıklarından elde edilen gübre, hayvan yemi, etonol üretimi, kozmetik sanayi, atık sulardan renk verici maddelerin uzaklaştırılması gibi alanlarda da kullanıldığı belirtilmektedir (Abalı vd., 2009: 201, 202; Bozkurt, 2012: 26; Çakır, 2015: 64).

Ayrica Hattox (1998: 61), Kuzucu ve Koz (2015: 281, 284), Alyakut ve Küçükkömürler (2018: 262, 263) tarafından yapılan araştırmalarda "geleneksel halk hekimliğinde insan sağlığı için kahvenin "temiz" kavramına uygunluğu tespit edilmiștir. Halk hekimliğindeki kullanım șekilleri şöyledir:

- "İshal tedavisinde iki kaşılk kahveye limon sıkılır ve üç saatte bir, birer kahve kaşığı az su ile yutulur.

- Bir miktar kahve mazı ile dövülür ve yenirse kabız etki eder.

- Bir miktar kahve toz edilir ve yara kurutucu olarak kesilen yaralara sürülür.

- Lohusalık sancısını kesici olarak şekerli kahve içilir.

- Baş ağrısına karşı limonlu kahve içilmesi önerilir.

- Baş ağrısına karşı halka halka kesilmiş ve bir yüzüne kahve ekilmiş patates dilimleri, başı ağrıyan kişinin alnına konur ve tülbentle sıkıca bağlanır. 
- Sitmaya karşı 40 gr. kahve, 50 gr. su ile kaynatılır ve kaynamış sudan hastaya içirilir." (Alyakut ve Küçükkömürler, 2018: 262, 263).

Osmanlı'dan bugüne süregelen Türk kahve kültürü içindeki geleneksel nice uygulama, "temiz" kavramına uygunluğu açısından değerlendirilebilir. Örneğin kahve sunumlarının bir tören havası içinde olması; kahve ikram merasimi sırasında sitil, fincan, zarf ve puşidelerin en ihtişamlı ve "temiz" olanlarının kullanılması söz konusudur. Kahve sunumuna sitil puşidesi adı verilen altın ve gümüş işlemeli kahve örtüleri, gümüş veya tombaktan yapılan sitil takımları ile elmas, yakut ve incilerle süslü fincan zarfları kullanılması belirtilebilir. Bu şekilde ihtişamlı olmamakla birlikte, halk arasında, hemen her evde, maddi imkânlar nispetinde özellikle "misafirlik" ve "çeyizlik" adı altında hazırlanan gümüş/bakır/porselen vb. kahve tepsileri; dantel/iğne oyası/Türkişii vb. kahve tepsisi örtüleri; fincan ve tabaklarının minik örtüleri; fincan ve cezve takımları; kahveyle sunulan özel su/șerbet bardakları, bardak ve fincan zarflarl; lokumluklar vb. bulunmaktadır ve bütün bunlar "temiz" kavramı dahilindedir (Koz vd., 2011: 20, 37; Işılkhan, 2014: 412).

Ayrıca kahve taneleri kavrulduktan sonra "temiz" mermer, tunç veya tahta bir havanda dövülerek pudra haline getirilmektedir. Kavrulmuş veya dövülmüş kahveler, kokusunu muhafaza edebilmesi için "temiz" deriden yapılmış torba veya kutularda saklanmaktadır (Kuzucu ve Koz, 2015: 313). Ulusoy tarafından yapılan bir araştırmada, kahve yanında verilen "temiz" içme suyunun önce içilmesinin "temiz su ağızdaki acılığı giderir, kahvenin tadını daha iyi almak için, kahvenin telvesinin boğaza yapışmaması için, kahvenin mideye zarar vermemesi için temiz su içilmesi" şeklinde belirtilmiştir (2011:9). Halk arasında kahveden önce su içilmesi, "tiryaki tarzı" kabul edilirken suyun kahveden sonra içilmesi "acemi tarzı" olarak kabul görmüş; "kahveyi sele vermek" șeklinde eleștiri konusu olmuştur. Bu kural, her iki durumda da su içildiği için yerine getirilmektedir.

Slow Food hareketinin ilkelerinden olan "temiz" felsefesi, Türk kahvesinin "temiz" kavramına göre pişirilmesi ile de yerine getirilmektedir:

- "İki kişilik ve doğrudan ısı kaynağı üzerinde bir seferde pişirilmesi tercih edilir (ön pişirmeye izin verilmez), kesinlikle hazır (instant) ürünler kullanilmaz.

- Kişi başı en az yedi gram Türk kahvesi kullanılır. (...)

- Soğuk kaynak suyu ile hazırlanır (yaklaşık üç dakikalık bir pişirme süresi gerektiren güçlü bir ısı kaynağı kullanılır). Önce su sonra Türk Kahvesi, şeker ve aromatik katkılar (varsa) ilave edilir. Cezveyi ateşe koymadan önce içeriği homojen bir kıvama erişene kadar tüm malzemelerin karıştırılması gerekir. (...) 
- Köpük elde etmek amacı ile (yöresel farklılıklar dışında) iki taşım ( $k a$ barma) pişirilir. (80 ${ }^{\circ} \mathrm{C}$ ve $95^{\circ} \mathrm{C}$ ) Kahvenin fokurdamamasına özen gösterilir. Fincana iki taşımdan aralıklı olarak Türk Kahvesi aktarılır"şeklinde tarif edilmiştir (Özgür, 2012: 3).

Bu durum Türk kahvesinin Slow Food hareketinin hem "temiz" kavramına uygunluğunu göstermektedir hem de aşırı içilmediği sürece insan sağlığına faydalı olduğu söylenebilir.

\section{“Adil” Kavramı Açısından Türk Kahvesi}

Sağır'ın çalışmasından hareketle Slow Food hareketine göre "adil" kavramı incelendiğinde, "yiyecek adil olmalıdır. Yiyecek üreticilerinin, kendi hakları korunurken ve değer verilirken, insancıl koşullarda yaptıkları iş içinde adil bir karşılık almalıdır" şeklinde ifade edilmiştir (2017: 54). Çakır ve diğerlerinin araştırmasında ise "adil" kahve kavramı "Tüketicilerin satın aldıkları gıdaların parasal değerini ödeyebildiği, çiftçilerin ve üreticilerin ürettikleri ve sattıkları gıdaların emeksel karşılı̆ı̆ı parasal değer olarak alabildiği ve koşulların adil olduğu bir gıda sektörünü" tanımlamaktadır. Ayrıca, adil gidanın önemli noktası, üreticinin hak ettiği ücret ve çalışma koşullarını sağlamak, üzerindeki baskıyı ve sömürüyü engellemektir (2015: 64).

Giddens, kahve üretiminin, hazırlanmasının, taşınmasının, pazarlanmasının ve geçirdiği diğer süreçlerin, onu içen binlerce kilometre uzaktaki insanlar arasında sürekli "adil" etkileșimi gerektirdiğini ifade etmiştir. Ayrıca, kahvenin "adil" şekilde Türklerin tarihini, kültürünü, dini uygulamalarını, ekonomisini, sosyolojisini ve folklorik derinliğini de içerdiğini ifade etmiştir (2004: 39, 40). Her ne kadar Türk kahvesinde genellikle en kaliteli kahve çekirdeği olan Arabica kullanılsa da daha uygun olan diğer kaliteli çekirdekler de kullanılabilmektedir. Aynı zamanda çiğ kahvelerin TSE 3900'ün şartlarına uygunluğu kontrol edilerek alt referansları adilce TSE 2'ye uygunluğunun incelenmesi şartı bulunmaktadır (Özgür, 2012: 1).

Bu durumda Slow Food hareketine göre "adil" kavramı incelendiğinde, kahve ile ilgili olarak ilk bakışta çelișkili bir durum söz konusu olabilir. Kahve, "adil" kavramı açısından ele alındığında "adilsizlikler" olduğu göze çarpabilir. Bu durum, "işçilerin emeklerinin sömürülmesi" şeklinde belirtilmiştir. Etiyopya Ticaret Borsasının üst düzey yöneticilerinden biri olan Ermias Eshetu ile yapılan görüşmede Eshetu, Etiyopya'daki kahve işçilerinin emeklerinin karşılığında günde bir dolar kazandığı, kahve zincirlerinin bir dolara çalışan işçilerin hazırladığı kahveyi üç dolara alıp iki yüz dolara sattığı şeklinde ifade ettiği hususlar adilsizlik göstergesidir (Habertürk (2017) http://www.haberturk.com/haber/haber/1353805-etiyopyada-kahve-iscilerinin-emek-mucadelesi/7 Erişim: 28.03.2018).

Ancak Türkler bu sömürge kültürünün dışındadır. Çünkü Türkler ne sömürge sahibidir ne de kahve üreticisidir. Kahve değerinden satın alınarak 
ithal edilmekte ve tüketiciye de düşük fiyattan ulaştırılmaktadır. Bu bağlamda Türk kahvesi "adil” bir içecek olarak nitelendirilebilir. Toplumdaki sosyoekonomik düzeyi farklı bireyler tarafından kolayca satın alınabilen bir içecek olduğu söylenebilir. D'ohsonn'un bu konudaki "Nerede olursa olsun, ister bir devlet büyüğü, ister bir şehirli, ister Müslüman, ister Hiristiyan olsun, ister evde, ister dükkânında, ister dairede, ister mağazada bulunsun; ister köyde, ister șehirde ziyarete gittiğiniz zaman, ev sahibi size mutlaka kahve ikram eder. Ĕger ziyaretiniz uzun sürerse, bir müddet sonra bir kahve daha, hatta biraz sonra bir üçüncü kahve daha gelir" ifadesi Türk kahvesinin ne kadar adil bir içecek olduğunu ortaya koymaktadır.

Wild tarafından yapılan çalışmada, "Adil Ticaret Hareketi”nin, 19. yüzyılda İngiltere'nin kooperatif sistemlerinde görüldüğü, Oxfam'ın 1960 yllında sisteme karşı olan bireylerle özdeșleşmesi ile daha belirgin hale geldiği belirtilmektedir. Nikaragua'da Sandistalara destek vermek amacıyla başlatılmış olan kahve inisiyatifinin Adil Ticaret için büyük bir adım olduğu belirtilmiştir. Hollanda'da 1988 yılında "Max Havelaar" etiketi teşebbüsü ile Adil Ticaret kavramına yeni bir kimlik kazandırılmıștır. Uluslararası Kahve Anlaşması'nın bozulması (1962 yılında kahve üreticileri arasında fiyatların değişimini önlemek için imzalanan anlaşmadır) ve Sandistaların 1990'da seçimi kaybetmesi ile Adil Ticaret kavramının marka olarak ortaya çıktığı belirtilmiştir (Wild 2004: 233). Adil Ticaret markası ile kahve ticaretinin daha adil olması ve ekolojik sistemi daha çok koruması sağlanmaya çalışılmıştır. Bu sayede kahvenin, sadece Türkiye'de değil dünyanın her ülkesinde adil bir şekilde tüketilebileceği ifade edilmiştir.

Türk kahve kültüründe sanayileşmenin izlerini de görmek mümkündür. En büyük yerli kahve markası Kuru Kahveci Mehmet Efendi Mahdumları'nın 20. yüzyılın başından itibaren üretimde mekanik sürece geçtiği, ulusal lojistik ağların gelişimine bağlı olarak ürünlerinin arttığı ve dağıtımın yaygınlaştığı belirtilmektedir (URL-3). Firmanın yabancı pazarlara girişi de hemen hemen aynı döneme rastlamaktadır. Fuarlar ve uluslararası kuruluşlarca düzenlenen etkinliklerde yer alması hem firmanın hem de Türk kahvesinin tanıtımı açısından küreselleşme akımının bir getirisi olarak değerlendirilebilir.

Slow Food hareketine göre, Türk kahvesinde istenilen tatlılığı para vererek satın aldığında ya da evinde içmek istediğinde tüketiciye "adil" şekilde kahve içimi için cezvedeki şeker miktarı şöyle olmalıdır:

- “Acl-şekersiz

- Az şekerli-1 kesme şeker (2-3 gr)

- Orta şekerli-1.5 kesme şeker (3-4.5 gr)

- SSekerli-2 kesme şeker (4-6 gr)" konularak hazırlandığında "adil” bir Türk kahvesi pişirme tekniği olduğu söylenebilir (Özgür, 2012: 3). 
Bu durumda Slow Food hareketine göre, bir fincan kahveyi yudumlama, geçmişte ve günümüzdeki toplumların "adilce" birbirlerine yaklaşımını temin etmektedir. Ayrıca ekonomik gelişmelerin "adil" olması, bireylerde farkındalığın ve bilinçliliğin artmasına etki ettiği söylenebilir.

\section{Sonuç}

Hızlı kentleşme ve değişen dünya konjonktürü ile Türk kahvesinde bir taraftan melezleşme izleri görülürken diğer taraftan kahve kültürü ve geleneğinin büyük oranda korunması açısından Slow Food hareketine uygun bir içecek olduğu tespit edilmiştir. Özellikle Eko Gastronomi turizminde Slow Food hareketinin "iyi, temiz ve adil" felsefesine uygun bir içecek olduğu söylenebilir. Türk kahvesinde Slow Food hareketinin "iyi, temiz ve adil” felsefesinin tüm özelliklerini karşılaması nedeniyle somut olmayan kültürel değerlerin korunmasında öncülük yapabileceği söylenebilir. Bu doğrultuda, Osmanlıların kahveyi bir cezve içinde pişirme tekniğinin gelecek kuşaklara kendine özgü özellikleri ile aktarılabilmesi için hazırlığı aşamasında kullanılan araç ve gereçlerin korunmasına; kısık atește yavaş yavaş pişirme metodunun sürdürülmesine; ikram adetlerinin uygulanmasına; ayrıca hem sıcak olduğu için hem de sohbet aracı olarak görüldüğü için yavaş yavaş içilme alışkanlığının aktarılabilmesine Eko Gastronomi turizmi içinde önemli bir imkân verilmelidir. Bu hususta sempozyumların, kongrelerin, workshopların düzenlenmesi, kahvenin hazırlanma, pişirilme ve ikram şekillerinin görsel olarak yapılması sağlanmalıdır. Bunlara ilaveten yurt içinde ve dışında mümkün olan her toplumsal uygulamada Türk kahve kültürünün ve geleneğinin doğru bir şekilde sürdürülebilmesi için organizasyon yapılmalıdır.

Ayrıca Türk kahvesi gibi mırra, şerbet, ayran gibi diğer geleneksel içeceklerin ve yiyeceklerin de benzer şekilde korunarak tescillenmesinin önü açılabileceği söylenebilir.

\section{KAYNAKÇA}

\section{Yazılı Kaynaklar}

ABALI, Yüksel ve diğerleri (2009). Türk Kahvesi Telvesinden Biyodizel Üretimi. Diyarbakır: V. Yenilenebilir Enerji Kaynakları Sempozyumu.

AKARÇAY, Erhan (2012). “Kah Kahvehane Kah Cafe: Küreselleşen Eskişehir'de Kahve Tüketimi Üzerine Kurumsal Bir Giriş". Aynalı Labirent Küreselleşen Kentte Tüketim İçinde (Ed.: Ali Ergur), Galatasaray Üniversitesi İletişim Dergisi, 2, 181-202.

AKGÜN, Nalan ve diğerleri (2013). "Kahve Telvesi İle Atık Sulardan Bakır Giderimi". Mühendislik ve Fen Bilimleri Dergisi Sigma, 31, s. 42-52.

AKŞİT AŞIK, Nuran (2017). "Değisşen Kahve Tüketim Alışkanlıkları ve Türk Kahvesi Üzerine Bir Araștırma". Journal of Tourism and Gastronomy Studies, 5 (4), s. 310-325 
ALYAKUT, Ömür - KÜÇÜKKÖMÜRLER, Saime (2018). “Türk Mutfak Kültüründe Kafein”. 17. Geleneksel Turizm Sempozyumu. Düzce Üniversitesi Yayınları 3(2): 254-264.

AYSELİ, Mehmet Turan (2015). Türk Kahvesinin Aroma ve Aroma-Aktif Bileșikleri Üzerine İki Farklı Kavurma İșleminin Etkisi. Adana: Çukurova Üniversitesi Fen Bilimleri Enstitüsü Yüksek Lisans Tezi.

BOZKURT, Belgin (2012). Kahve Telvesiyle Atık Sulardan Ağır Metal Absorpsiyonu. İstanbul: Yıldız Teknik Üniversitesi Fen Bilimleri Enstitüsü Yüksek Lisans Tezi.

BULDUK, Sıdıka - SÜREN, Tufan (2007). “Türk Mutfak Kültüründe Kahve”. 38. ICANAS (Uluslararası Asya ve Kuzey Afrika Çalışmaları Kongresi, s. 299-309.

ÇAKIR, Ali ve diğerleri (2015). Bilinçli Mutfak. Ankara: Beta Basım Yayın

ÇEPNİ, Salih (2010). Araştırma ve Proje Çalışmalarına Giriş. 5. b., Trabzon.

DEMİKOL, Neslihan (2013). "Bir Masa Etrafında Toplanmak: Kültürler Arasılığın Hayata Geçirilme Alanı Olarak Sofra ve Mutfak". Aynı Tadı Paylaşmak: TürkiyeRomanya Geleneksel Ortak Mutfağı Çalıştay Bildirileri, s. 23-30, Ankara: Unesco Yayınları.

GIDDENS, Anthony (2004). Sosyoloji. (Çev.: Cemal Güzel), Ankara: Ayraç Yayınevi.

GÜRSOY NASKALİ, Emine (2011). (Ed.) Türk Kahvesi Kitabı. İstanbul: Kitabevi Yayınları.

GÜVEN, Erdem (2011). “Yavaş Güzeldir: Yavaș Yemek'ten Yavaş Medya'ya Hızlı Tüketime Dair Bir Çözüm Önerisi”. Selçuk Üniversitesi İletişim Fakültesi Akademik Dergisi, 7 (1), s. 113-121.

Habertürk (2017). http://www.haberturk.com/haber/haber/1353805-etiyopyada-kahve-iscilerinin-emek-mucadelesi/7 (Erişim: 28.03.2018).

HANNERZ, Ulf (1998). “Çevre Kültür Senaryoları”. Kültür Küreselleşme ve Dünya-Sistemi: Kimlik Temsilinin Çağdaş Koşulları. (Der.: Anthony D. King, Çev.: Gülcan Seçkin ve Ümit Hüsrev Yolsal), s. 139-163, Ankara: Bilim ve Sanat Yayınları.

HATTOX, Ralph S. (1996). Kahve ve Kahvehaneler. (Çev.: Nurettin Elhüseyni), İstanbul: Tarih Vakfı Yurt Yayınları.

HOŞTUT, Begüm ve diğerleri (2011). Atık Kahve Telvesinden Aktif Karbon Üretimi. TÜBİTAK-BİDEB Kimyagerlik, Kimya Öğretmenliği ve Kimya Mühendisliği Kimya Lisans Öğrencileri Araştırma Projesi Eğitimi Çalıştayı.

IŞIKHAN, Serap Savaş (2014). “Türk Kahvesi Geleneği ve Kahve Fincanları”. Türk Kahvesi Kitabı, (Ed.: Emine Gürsoy Naskali), s. 407-420, İstanbul: Kitabevi Yayınları.

KARALAR, Rıdvan - KİRACI, Hakan (2011). “Çevresel Sorunlara Karşı Bir Çözüm Önerisi Olarak Sürdürülebilir Tüketim Düşüncesi”. Sosyal Bilimler Dergisi, S. 30, s. 63-76.

KARASAR, Niyazi (2007). Bilimsel Araştırma Yöntemleri. Ankara: Nobel Yayınları. 
KESKINN, Enes Battal (2012). "Sürdürülebilir Kent Kavramına Farklı Bir Bakış: Yavaş Şehirler (Cittaslow)”. Paradoks Ekonomi, Sosyoloji ve Politika Dergisi, 8 (1), s. 84-99.

KOZ, Gül Fatma ve diğerleri (2011). Tüm Zamanların Hatırına Sarayda Bir Fincan Kahve. İstanbul: TBMM Saraylar.

KUZUCU, Kemallettin ve KOZ, Sabri (2015). Türk Kahvesi. İstanbul: Yapı Kredi Yayınları.

KÜÇÜK, Berna - KAHYAOĞLU, İrem (2013). "Yerellik Öğeleri İçinde Küreselleşen Yönetmen: Ferzan Özpetek". The Turkish Online Journal of Design, Art and Communication, S. 2, s. 57-66.

MERRIAM, Sheran B. (2015). Nitel Araştırma Desen ve Uygulama İçin Bir Rehber. Ankara: Nobel Yayınları.

ÖZGÜR, Naci (2012). Türk Kahvesi Standartları ve Pişirme Ekipmanları Teknik Analizi. Türk Kahvesi Kültürü ve Araştırmaları Derneği.

SAĞIR, Gülhan (2017). "Küreselleșmeden Geleneksele Dönüşte Slow Food ve Cittaslow Hareketi”. The Journal of Social Science, 1 (2), s. 50-59.

SALTAN, Fatma Zerrin - KAYA, Helin (2018). "Kahve: Bir Farmakognozik Derleme”. FABAD Journal of Pharmaceutical Sciences, 43 (3), s. 279-289.

SHERIDAN, Clare (2004). Sade Türk Kahvesi. (Çev.: Zeynep Güden), İstanbul: Arion Yayınevi.

TOROS, Taha (1998). Kahvenin Öyküsü. İstanbul: İletişim Yayınları

ULUSOY, Kadir (2011). “Türk Toplum Hayatında Yaşatılan Kahve ve Kahvehane Kültürü”. Millî Folklor, S. 89, s. 159-169.

WILD, Antony (2004). Kahve: Bir Acı Tarih. (Çev.: Ezgi Ulusoy). İstanbul: MB Yayınevi.

YILDIRIM, Ali - ŞİMŞEK, Hasan (2006). Sosyal Bilimlerde Nitel Araştırma Yöntemleri. Ankara: Seçkin Yayıncılı.

\section{Elektronik Kaynaklar}

URL-1: $\quad$ http://aregem.kulturturizm.gov.tr/TR-202374/turk-kahvesi-kulturu-vegelenegi.html. (Erişim tarihi: 27.05.2019).

URL-2: http://turkkahvesidernegi.org/\# (Erişim Tarihi: 27.05.2019).

URL-3: http://www.mehmetefendi.com/mehmetefendi/tr/pages/kkme3.html Erişim: (28.03.2018). 